\title{
Physiological, Biochemical, and Genotoxic Effects of Wastewater on Maize Seedlings
}

\author{
Muhammad Khan Daud ${ }^{1,2 *}$, Saeed Hassan², Azizullah Azizullah ${ }^{3}$, Muhammad Jamil², \\ Naeem Rehan², Raza Irum², Muhmmad Khan Qaiser², Shui-Jin Zhu ${ }^{1 *}$ \\ ${ }^{1}$ Institute of Crop Science, College of Agriculture and Biotechnology, Zhejiang University, \\ Hangzhou, China \\ ${ }^{2}$ Department of Biotechnology and Genetic Engineering, Kohat University of Science and Technology, \\ 26000, Pakistan \\ ${ }^{3}$ Department of Botany, Kohat University of Science and Technology, \\ 26000, Pakistan
}

Received: 1 October 2014

Accepted: 11 December 2015

\begin{abstract}
Wastewater not only provides nutrients to the plant community but may cause abiotic stress conditions due to the presence of toxic substances. The present study was designed to explore wastewater-induced changes in maize seedlings using four different concentrations $(0,10,50$, and $100 \%)$ collected from three different sources, i.e., municipal wastewater (designated as MW), woolen mill wastewater (designated as WW) and polyvinylchloride wastewater (designated as PW) of the city of Bannu situated in Khyber Pakhtunkhwa, Pakistan. All physiological parameters such as germination, biomass, and length of maize seedlings gradually slowed down with the increase in wastewater concentration. Similarly, the photosynthetic pigments decreased, while an increase was calculated in $\mathrm{Na}^{+}$and $\mathrm{Ca}^{++}$and $\mathrm{K}^{+}$ions in our present experiment. The malondialdehyde (MDA) and hydrogen peroxide $\left(\mathrm{H}_{2} \mathrm{O}_{2}\right)$ contents as well as antioxidative enzymes such superoxide dismutase (SOD), peroxidase (POD), ascorbate peroxidase (APX), and catalase (CAT) upregulated in all treated samples, while total soluble proteins increased. Various wastewater sources also caused genotoxic effects as revealed by the appearance and disappearance of various bands at DNA and protein levels. The present study reveals that different sources of wastewater caused differential stresses in maize seedlings, which might be due to the presence of different stressful agents in them.
\end{abstract}

Keywords: DNA damage, oxidative metabolism, physiology, sewage water, Zea mays L.

\section{Introduction}

Unlike other commodities of life such as oil and wheat, fresh water has no substitute for most of its uses [1]. It is

$\overline{\text { *e-mail: mkdaud@yahoo.com }}$ shjzhu@zju.edu.cn a basic component of life. The total amount of available fresh water is almost 3\%. Unfortunately, this available percentage is being contaminated by rapid increases in population, urbanization, and industrialization. In developing countries, like Pakistan, both industrial and municipal wastewater is used for irrigation purpose. The main reason behind the use of wastewater for irrigation 
is the presence of valuable organic materials and plant nutrients $[2,3]$.

However, wastewater also introduces various inorganic and organic toxic substances to soil [4]. Wastewater, mainly from pesticide-spray areas, sewage sludge, and domestic and industrial wastes contains toxic heavy metals such as cadmium, lead, and arsenic, etc. Therefore, its constant use over periods of time may badly affect soil quality and plant growth [5]. Apart from this, they may be largely assimilated by aquatic species, passed through the food chain, and might be responsible for such afflictions as cancer and cardiovascular diseases. Although the basic mechanisms are still unknown, experimental evidence suggests their genotoxic effects on human health [6].

Since these pollutants are toxic, they cause stressful situations in both plants and animals that result in oxidative damage to the cellular components of the cells due to the production of various reactive oxygen species (ROS). These are extremely toxic and can alter membranes' functions by changing lipid composition as well as affecting the enzymatic activities of the cells [7]. Their toxicological effects may either be acute or chronic, and can occur at all levels of biological organization - from the molecular to the ecosystem levels [6]. Against such oxidative damage, plants activate various antioxidative enzymes systems, namely superoxide dismutase (SOD), peroxidase (POD), ascorbate peroxidase (APX), and catalase (CAT). They are the most important components of the defensive systems of living beings. They are capable of scavenging these ROSs by converting them into harmless substances such as $\mathrm{H}_{2} \mathrm{O}_{2}$ and $\mathrm{O}_{2}[6]$.

These stressful agents also alter the genetic architecture of targeted organisms, which can be assayed using various techniques such as restriction fragment length polymorphism (RFLP), quantitative trait loci (QTLs), randomly amplified polymorphic DNA (RAPD), amplified fragment length polymorphism (AFLP), simple sequence repeats (SSRs), variable number tandem repeats (VNTRs), and sodium dodecyl sulfate polyacrylamide gel electrophoresis (SDS-PAGE). They are DNA- and proteinbased assays used to measure the genotoxic effects of pollutants. DNA-based RAPD studies have been widely done for measuring heavy metals-induced genotoxicity [8] by simply recording the disappearance and/or appearance of DNA fragments, total numbers of polymorphic and monomorphic bands, and band size and intensity in both treated and non-treated samples of agent studies.

Maize (Zea mays L.) is an important food crop mostly in Africa and provides food for humans, feed for animals (especially poultry and livestock), and raw material for industry [9] . It is the most important cereal crop after wheat and rice in Pakistan, while it ranks second after wheat in Khyber Pakhtunkhwa Province [10]. We designed our present study keeping in mind the global use of wastewater for irrigation and the presence of toxicants in various sources of waster as well as the vast use of maize. Our main aims were to investigate the toxic effects of municipal and industrial wastewater on physiology and biochemistry of maize seedlings, as well as to explore the oxidative and genetic effects in maize seedlings induced by different concentrations of wastewater.

\section{Materials and Methods}

\section{Sampling of Wastewater and Maize Culturing Conditions}

Three different types of wastewater from three different sources, i.e., municipal wastewater (designated as MW), woolen mill wastewater (designated as WW), and polyvinylchloride wastewater (designated as PW) of the city of Bannu in Khyber Pakhtunkhwa, Pakistan, were used in the present study. They were collected in wellwashed dark bottles and were immediately stored at $4^{\circ} \mathrm{C}$ after filtration using Whatman filter paper. Four different concentrations of all three samples were used, including control (i.e., 0, 10, 50, and $100 \%$ ).

Uniform-sized seeds of maize (cv. Azam) were cultured in sterilized sand after their surface sterilization with $80 \%$ $(\mathrm{v} / \mathrm{v})$ ethanol at $28 \pm 2^{\circ} \mathrm{C}$ in a growth chamber using a $14: 10$ hour photoperiod. For first three days, complete dark conditions were provided while on day four, light conditions were provided with white fluorescent light. The relative humidity inside the growth chamber was kept at $60 \%$.

\section{Physiological Assays}

Independent experiments were run for various measurements of germination, root/shoot lengths, and fresh and dry weights. For germination assay, seeds were germinated in sterilized petri dishes containing singlelayered Whatman filter paper. For each treatment, three replications with 10 seeds per replication were used. $10 \mathrm{ml}$ nutrient solution was used for each treatment. Seeds were allowed to germinate up to three days. Seeds having $2 \mathrm{~mm}$ radical length were considered germinated.

For the measurements of various physiological parameters such as root/shoot length, their fresh and dry biomass, leaf length and width, seedlings were grown for 10 days. The above parameters were measured on day 11 . To determine dry biomass, both roots and shoots were oven dried at $80^{\circ} \mathrm{C}$ for 72 hours.

\section{Biochemical Assays}

Both roots and shoots were also subjected to various biochemical analyses such as photosynthetic pigments (chlorophyll $a$, chlorophyll $b$, and carotenoids), ions $\left(\mathrm{Na}^{+}, \mathrm{K}^{+}, \mathrm{Ca}^{2+}\right)$, lipid peroxidation, total soluble proteins, hydrogen peroxide $\left(\mathrm{H}_{2} \mathrm{O}_{2}\right)$, and ROS-scavenging enzymes (POD, APX, CAT).

Chlorophylls a and $b$ as well as carotenoids were determined using the method of [11]. $25 \mathrm{mg}$ sundried leaves and roots of each treatment were taken in test tubes. $5 \mathrm{ml}$ methanol was added to each test tube. Methanolic extract was used for the measurements of chlorophyll $a$, chlorophyll $b$, and carotenoids. 
A modified method of [12] was used to determine ions. The oven-dried roots and leaves of maize seedlings were ground to fine powder for ion analysis using a flame photometer. $25 \mathrm{mg}$ dry material of both roots and leaves was used in this experiment.

Cell viability was quantified in both roots and leaves using TTCand electrolyteleakagemethods. Dehydrogenase activity was measured using triphenyltetrazolium chloride (TTC) salt according to the protocol of [13]. For the measurement of electrolyte leakage in both roots and leaves we used the method of [14].

In order to determine lipid peroxidation, hydrogen peroxide, and total soluble protein, $0.5 \mathrm{~g}$ fresh sample of both roots and leaves were taken. Materials were crushed $8.0 \mathrm{ml}$ of TCA $(0.1 \%, \mathrm{w} / \mathrm{v})$ in ice-cold conditions, and the homogenate was centrifuged at $14,000 \mathrm{~g}$ for $20 \mathrm{~min}$. Lipid peroxidation, hydrogen peroxide $\left(\mathrm{H}_{2} \mathrm{O}_{2}\right)$, and total soluble proteins were determined using the protocols described by [7] using bovine serum albumin as a standard.

For the determination of various ROS scavenging assays, fresh samples of roots and leaves were crushed in cold $5 \mathrm{ml} 50 \mathrm{mM}$ extraction buffer (PBS 7.8). Ascorbate peroxidase (APX) (EC 1.11.1.11), catalase (CAT) (EC1.11.1.6), and peroxidase (POD) (EC1.11.1.7) activities were determined according to the protocols mentioned in [7].
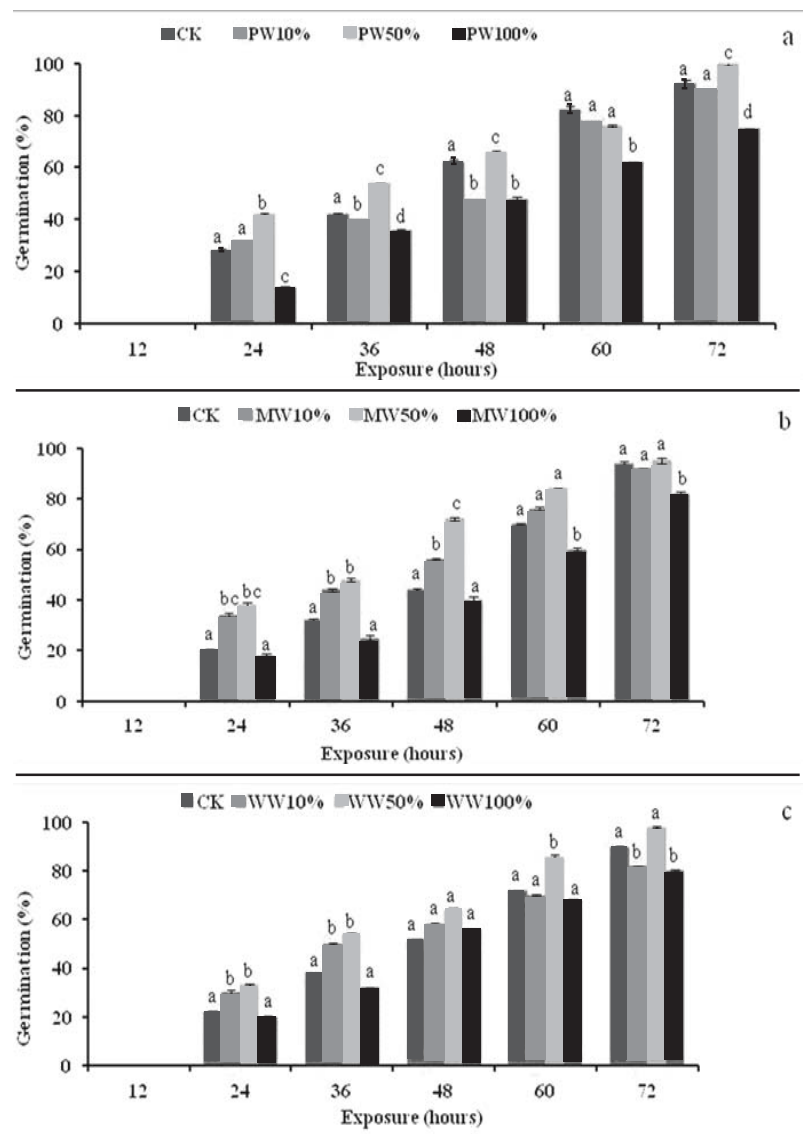

Fig. 1. Effects of: (a) polyvenyl chloride water (PW), (b) muncipal water (MW), (c) on the germination percentage of maize seeds.

\section{Genotoxicity Assays}

In order to properly assess the genotoxic effects of various sources of wastewater on maize seedlings, the entire genomic DNA was extracted from leaves of maize plants using a DNA extraction kit, and DNA amplification was performed based on Ray methodology for arbitrary polymerase chain reaction (PCR) according to the protocol of [15].

Sodium dodecyl sulfate (SDS) polyacrylamide gel electrophoresis (PAGE) was used for protein damage analysis in leaf samples of both control and sewagetreated plants as described by Laemmli [16].

\section{Statistical Analysis}

The replicated data were subjected to one-way analysis of variance (ANOVA) using STATIX9 in order to determine the statistical difference among various treatments at 5\% probability level. All the data are the means \pm SE of three replications. Means were separated by least significant difference (LSD) test at 5\% level of significance.

\section{Results and Discussion}

Wastewater is usually very rich in organic materials and plant nutrients, and is mostly used to increase crop productivity in developing countries. It also contains toxic substances that may directly or indirectly influence the growth and development of the plants being irrigated with it. In our present in vivo experiment, we studied the physiological and biochemical response reactions of the maize under increasing concentrations of sewage wastewater.

\section{Sewage Water Stress Strongly Influences} the Germination Capability of Maize Seeds

Seed germination and seedling growth are very responsive to environmental changes. Germination percentage decreased with increasing sewage water stress from 0 to $100 \%$ dilution (Fig. 1(a-c)). Maize seed could not be germinated after 12 hours at all levels of all three different samples; however, significant germination occurred at all other timings. The germination percentage was almost higher at 10 and $50 \%$ dilution as compared with their respective controls, except at 100\% dilution. Germination percentage declined at $100 \%$ dilution in all three samples. It was significantly lower than the controls in PW samples at all timings. After 24 hours, 10\% germination was noted in control, while $10 \%$ dilution of sample PW and MW resulted in only $2 \%$ germination. All samples of wastewater PW (Fig. 1(a)), MW (Fig. 1(b)), and WW (Fig. 1(c)) the germination percentage was very slow as compared to control, In MW samples, germination significantly decreased at $100 \%$ dilution in comparison with control after a 60- and 72-hr germination period, 
while WW wastewater samples a decline in germination could be noticed only at $100 \%$ dilution only after a $72-\mathrm{hr}$ germination period. As a whole, germination percentage was badly affected at $100 \%$ dilution in the PW wastewater sample at all germination periods. Our present findings are in line with Nagda et al. [17], who found lower seed germination in wheat and mug bean seeds at higher concentrations of industrial effluents. This could be due to an increase in the osmotic potential of the effluents at greater concentration of total salts, making imbibition more difficult and ultimately retard germination efficiencies.

Sewage Water Stress Negatively Affects the Biometric Parameters of Maize Seedlings

Wastewater and industrial water mostly used for irrigation purposes usually contain heavy metals like Fe, $\mathrm{Mn}, \mathrm{Zn}, \mathrm{Pb}, \mathrm{Cr}, \mathrm{Cd}$, Ni, or Co [18, 19]. They inhibit growth in terms of biomass reduction [20]. According to Fig. 2(ad), we recorded a decrease in biomass (fresh and dry) and length (root and shoot) in maize seedlings with the increase in external application of sewage water concentration as compared to control. Significant reductions were found in shoot dry weight and shoot lengths in all treated samples. Moreover, shoot fresh weight of sewage-treated plants of
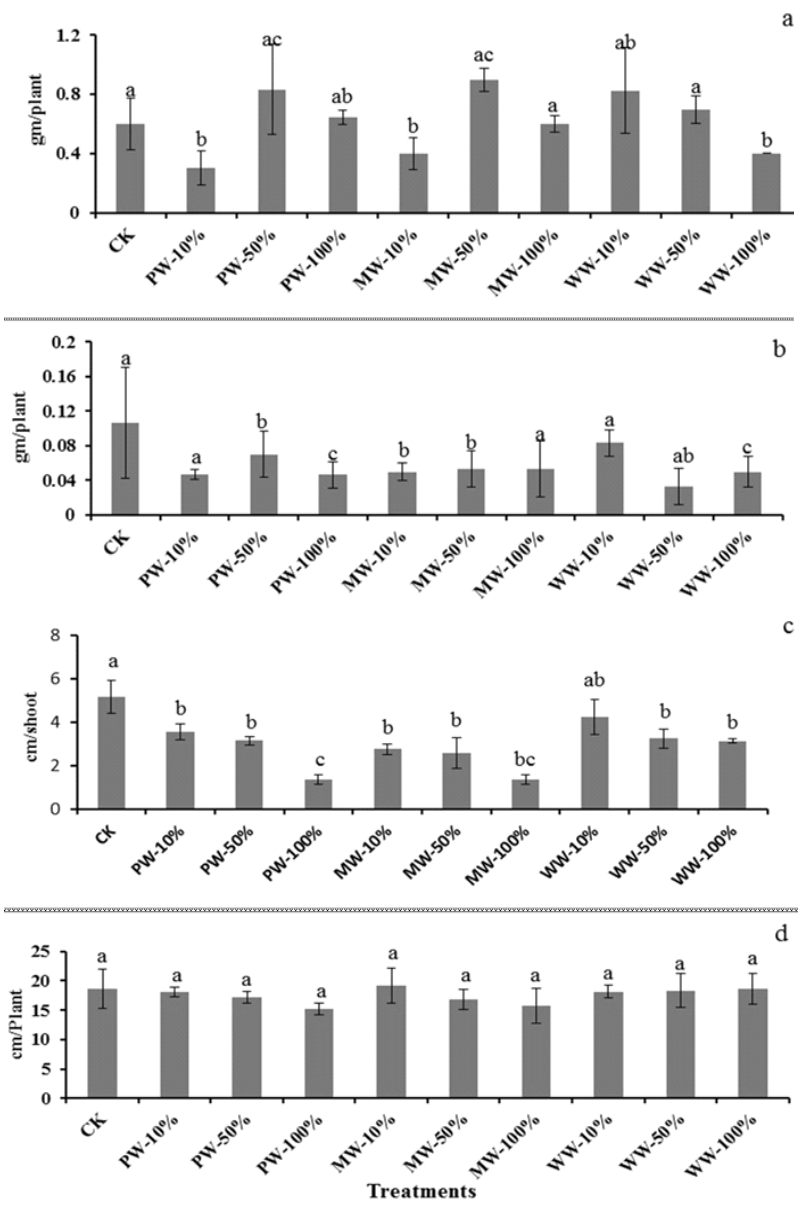

Fig. 2. Effects of PW, MW, and WW on: (a) shoot fresh weight, (b) shoot dry weight, (c) shoot length, (d) root length.
PW and MW and WW samples were higher than control (Fig. 2a). According to Doke et al. [21], a decrease in biomass with an increase in concentration of wastewater may be due to the presence of heavy metals in the form of $\mathrm{Pb}, \mathrm{Zn}, \mathrm{Cu}, \mathrm{B}$, and $\mathrm{Cd}$. Domestic wastewaters are rich in organic materials and plant nutrients such as $\mathrm{K}, \mathrm{Ca}, \mathrm{Cu}$, $\mathrm{Mn}$, and $\mathrm{Zn}$, which increase the crop yield [22].

The results of root and shoot lengths also indicated some variation in different treatments compared to control (Fig. $2(c-d)$ ). Data revealed a decrease in shoot and root length of maize seedlings with the increase in concentrations of different sewage waters compared to control. Shoot length was reduced from $5.16 \mathrm{~cm}$ to 2.43 and $2.43 \mathrm{~cm} /$ plant at control, 50 and $100 \%$ concentration of PW, respectively. Similarly, root length of maize seedlings in control was about $18.60 \mathrm{~cm}$, while in $10 \%$ concentrations of WW and MW samples root length remained 19.20 and $20.24 \mathrm{~cm}$ per plant, respectively. These results state that the PW, $\mathrm{MW}$, and WW industry effluents caused greater damage to shoots compared to roots. This could be due to the presence of toxic substances in the sewage water, which might have badly damaged the chloroplast machinery of the leaves. Our observations are further confirmed by an overall decline in the photosynthetic pigments. Our present findings are in line with the findings of Khan et al. [23] in wheat Bazai and Achakzai [24] in lettuce.
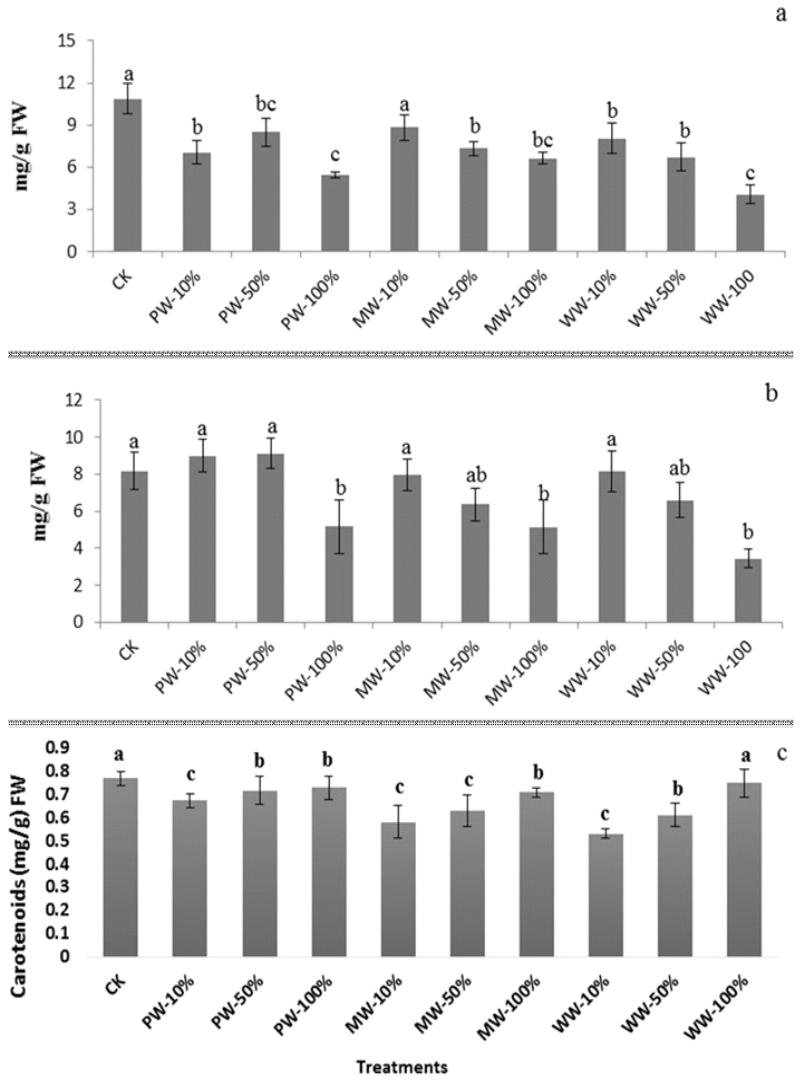

Fig. 3. Effects of PW, MW, and WW on: (a) chlorophyll $a$, (b) chlorophyll $b$, (c) carotenoids. 
Wastewater Sources Have a Negative Influence on the Photosynthetic Machinery of Maize Seedlings

Results regarding the effects of wastewater from various sources on maize seedlings revealed a decline in chlorophyll a and b, and carotenoid contents in sewagetreated maize plants (Fig. 3(a-c)). Similarly, their contents gradually decreased with the gradual increase in concentrations of wastewater. Maximum chlorophyll $a$ reduction was observed at $100 \%$ concentration, i.e., $4.8 \mathrm{mg} / \mathrm{g} \mathrm{FW}$ in $\mathrm{PW}, 6.2 \mathrm{mg} / \mathrm{g} \mathrm{FW}$ in $\mathrm{MW}$, and $4 \mathrm{mg} / \mathrm{g}$ FW in WW were recorded compared to control $(10.8 \mathrm{mg} / \mathrm{g} \mathrm{FW})$. When plants were exposed to 10 and $50 \%$ $\mathrm{PW}$, an increase ( $9.0 \mathrm{mg} / \mathrm{g} \mathrm{FW})$ in chlorophyll ' $b$ ' contents was noticed, but when exposed to higher concentrations, i.e., $100 \%$, a decrease up to $5.9 \mathrm{mg} / \mathrm{g} \mathrm{FW}$ was recorded. Similarly, in treatments of MW and WW chlorophyll, ' $b$ ' content decreased continuously with the increased concentrations of sewage water (Fig. 3(b)). The degradation of chlorophyll pigments under sewage water stress could be linked with increased activity of chlorophyllase or reduced de novo synthesis of chlorophyll [25]. In Fig. 3(c), carotenoid contents were recorded in plants when exposed to $100 \%$ concentration in PW $(0.71 \mathrm{mg} / \mathrm{g} \mathrm{FW})$, MW $(0.72 \mathrm{mg} / \mathrm{gFW})$, andWW $(0.72 \mathrm{mg} / \mathrm{gFW})$ comparedtocontrol $(0.75 \mathrm{mg} / \mathrm{g} \mathrm{FW})$.

\section{Wastewater Stress Results in an Increase in Various Ions $\left(\mathrm{Na}^{+}, \mathrm{Ca}^{++}\right.$, and $\left.\mathrm{K}^{+}\right)$}

As wastewater stress imposed an imbalance in ion contents of experimental plants, ion analysis of major macronutrients $\left(\mathrm{Na}^{+}, \mathrm{Ca}^{++}, \mathrm{K}^{+}\right)$was done in shoots and roots (Fig. 4(a-b). The present results showed that there is a constant increase in $\mathrm{Na}+$ and $\mathrm{Ca}++$ level of shoots with an increase in sewage water concentrations. Results indicated that the lowest quantity of ions were measured in control (10 and $21 \mu \mathrm{g} / \mathrm{g} \mathrm{DW})$, while the highest $\mathrm{Na}^{+}$ and $\mathrm{Ca}^{++}$values were observed at $100 \%$ concentrations for PW (27 and $31 \mu \mathrm{g} / \mathrm{g} \mathrm{DW})$, MW (24 and $29 \mu \mathrm{g} / \mathrm{g}$ DW), and WW (22 and $32 \mu \mathrm{g} / \mathrm{g}$ DW). Furthermore, $\mathrm{K}^{+}$ level increased up to $50 \%$ in plants treated with different wastewater sources, i.e., PW ( $24 \mu \mathrm{g} / \mathrm{g}$ DW), MW ( $27 \mu \mathrm{g} / \mathrm{g}$ DW), and WW (22 $\mu \mathrm{g} / \mathrm{g} \mathrm{DW})$, and then declined at $100 \%$ concentration of all treatments, i.e., PW $(18 \mu \mathrm{g} / \mathrm{g} \mathrm{DW})$, MW (16 $\mu \mathrm{g} / \mathrm{g} D W)$, and WW (19 $\mu \mathrm{g} / \mathrm{g} D W)$. Similarly, ion analysis in roots showed the same trend. Municipal waste increased the amounts of available macronutrients such as $\mathrm{Ca}^{2+}, \mathrm{K}^{+}$, and $\mathrm{Na}^{+}$ions in the plants, therefore an increased level of ions was observed in the roots and shoots.

\section{Wastewater Stress Strongly Influences Cell Viability}

Cell viability in shoots and roots was determined using both TTC and electrolyte leakage methods (Fig.s 5(a-b)). According to Fig. 5(b), shoots and roots of maize seedlings grown in controlled conditions had values of 22.04
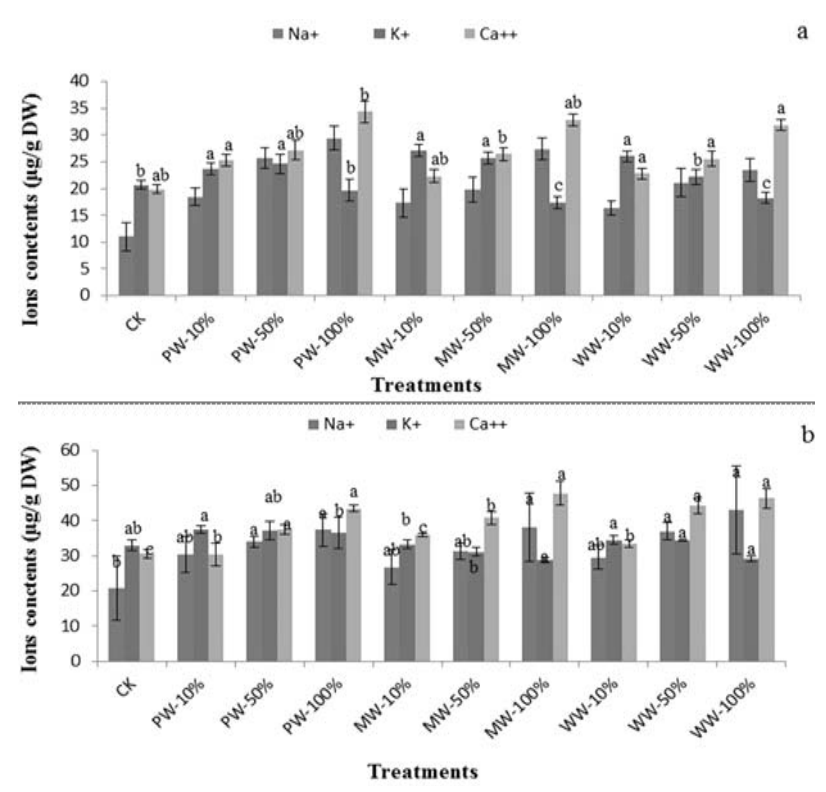

Fig. 4. Effects of PW, MM, and WW on $\mathrm{Na}^{+}, \mathrm{K}^{+}$, and $\mathrm{Ca}^{++}$ions of: (a) shoots, (b) roots .

and $16.03 \mu \mathrm{s} / \mathrm{cm}$ in comparison with $100 \%$ concentration of WW sample, which had values of about 37.6 and $26.23 \mu \mathrm{s} / \mathrm{cm}$. The electrolyte leakage values of plants, grown in PW sewage water sample, were, respectively, 28.7 and $17.45 \mu \mathrm{s} / \mathrm{cm}$ at $50 \%$ concentration, and 36.5 and $19.54 \mu \mathrm{s} / \mathrm{cm}$ at $100 \%$. However, cell damage was insignificant for other samples. Fig. 5(a) depicts the cell viability measurement in roots and shoots using the TTC method. Results indicated that the number of viable cells in both shoots and roots decreased with the increase in concentration of the sewage water in all samples. Minimum damage was done at $10 \%$ concentration.

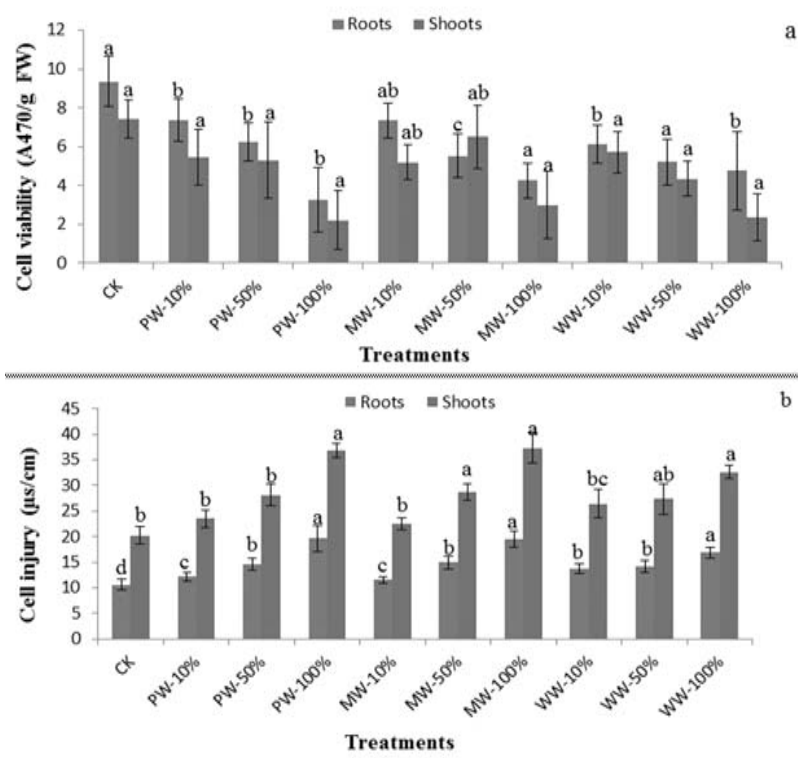

Fig. 5. Effects of PW, MW, and WW on: (a) cell viability, (b) cell injury of roots and shoots. 
Sewage Water Stress Differentially Affected Total Soluble Proteins, $\mathrm{H}_{2} \mathrm{O}_{2}$, and MDA Contents

Sewage water rich in heavy metals such as $\mathrm{Cu}, \mathrm{Zn}$, and $\mathrm{Pb}$ can cause the production of reactive oxygen species (ROS), which affect mainly lipids and proteins [26]. In order to determine the toxic effects of sewage water, we carried out various assays such as total soluble proteins, MDA contents, and $\mathrm{H}_{2} \mathrm{O}_{2}$ (Fig. 6(a-c)). According to mean data, the total soluble protein contents decreased in leaves of maize seedlings in all sources of sewage waters (Fig. 6a) as compared to MDA and $\mathrm{H}_{2} \mathrm{O}_{2}$ contents, which increased as a whole. The decrease in total soluble proteins might be due to disturbances in the chloroplast of leaves of treated seedlings.

Hydrogen peroxide is one of the lethal ROSs as it inhibits the Calvin cycle and consequently reduces the carbon fixation. Lower levels of $\mathrm{H}_{2} \mathrm{O}_{2}$ are involved in different signaling processes [27]. However, plants tend to accumulate higher levels of $\mathrm{H}_{2} \mathrm{O}_{2}$ under effluent stress that causes substantial degradation of photosynthetic pigments [28]. Fig. 6(b) shows the increased level of $\mathrm{H}_{2} \mathrm{O}_{2}$ at all levels of sewage water stress. Lipid peroxidation in terms of MDA contents is a significant indicator of oxidative damage to membranes under stressful conditions [26]. The effect of sewage stress on lipid peroxidation in maize plants and MDA contents were determined (Fig. 6(c)). Under all sewage water stress conditions, MDA contents clearly increased from 10 to $100 \%$ concentrations. Effluent-induced increases in MDA have been reported in maize $[27,25]$. Increases in MDA contents clearly convey a message that membranous structures of the cell have been damaged by all sources of wastewaters due to the production of peroxides such as $\mathrm{H}_{2} \mathrm{O}_{2}$. Furthermore,
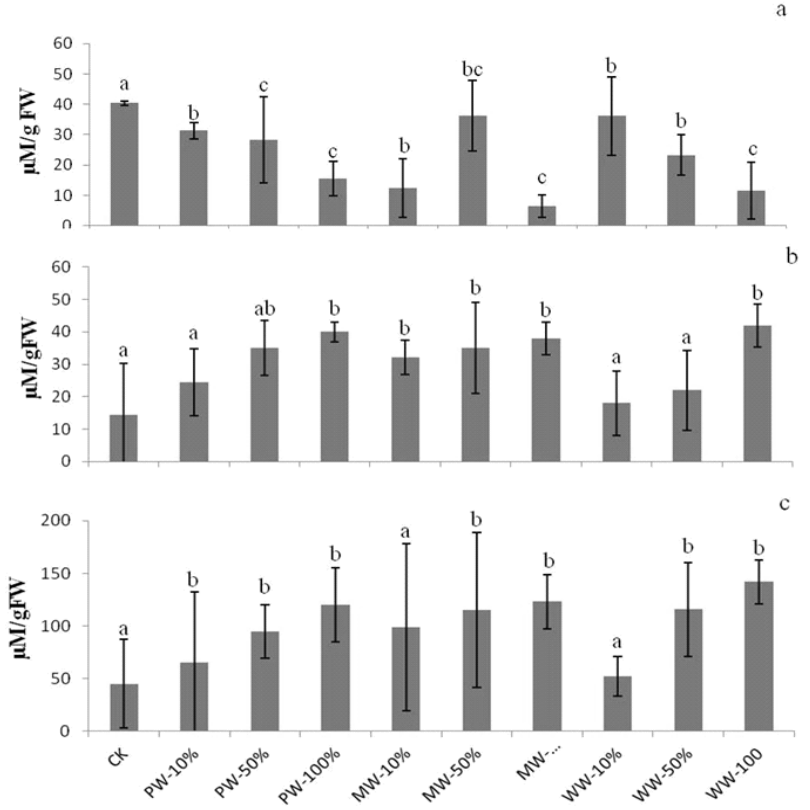

Fig. 6. Effects of PW, MW, and WW on: (a) total protein contents, (b) $\mathrm{H}_{2} \mathrm{O}_{2}$, (c) MDA of leaves. increases in these MDA and $\mathrm{H}_{2} \mathrm{O}_{2}$ contents have caused a decline in total soluble proteins.

\section{Effect of Sewage Water on Oxidative Metabolism Levels in Maize Seedlings}

Antioxidative enzymes play active roles in scavenging ROS produced in plants under environmental stresses. APX is the most essential ROS scavenging enzyme [29], which can detoxify $\mathrm{H}_{2} \mathrm{O}_{2}$ under abiotic stress. Fig. 7(a-c) show various antioxidative enzyme activities in the form of APX, POD, and CAT. APX activity (Fig. 7(a)) in the sample treated with $10-100 \%$ PW concentrations was increased from 320 to $350 \mathrm{mM} / \mathrm{g} \mathrm{FW}$, respectively, while APX activity in samples treated with MW decreased from 10 to $100 \%$ concentrations, i.e. 261 to $273 \mathrm{mM} / \mathrm{g} \mathrm{FW}$. In the case of a sample treated with WW, the APX activity in 10 and $100 \%$ concentrations were higher by about 276 and $290 \mathrm{mM} / \mathrm{g} \mathrm{FW}$. But at 50\% concentration APX activity was $260 \mathrm{mM} / \mathrm{g}$. All three samples in various concentrations showed higher activity of APX control $(245 \mathrm{mM} / \mathrm{g} \mathrm{FW})$. In the present study, the APX activity increased in all sewage-treated plants at $100 \%$ concentrations. Similar findings have been reported by Razinger [30].

POD is an important antioxidant enzyme. Its activity either increased or decreased in plants under heavy metals stress [29].The peroxidase activity (POD) in maize grown under various sewage stresses caused a
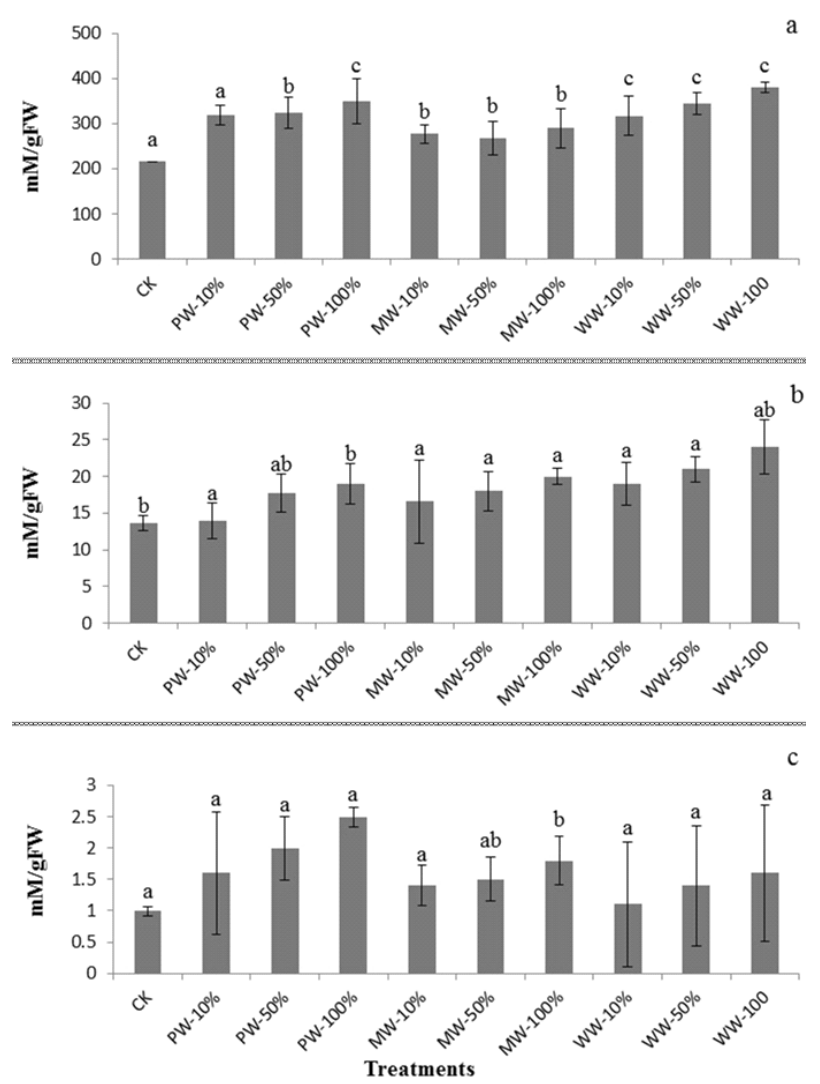

Fig. 7. Effects of PW, MW, and WW on: (a) APX, (b) peroxidase, (c) catalase activities in leaves of maize seedlings. 


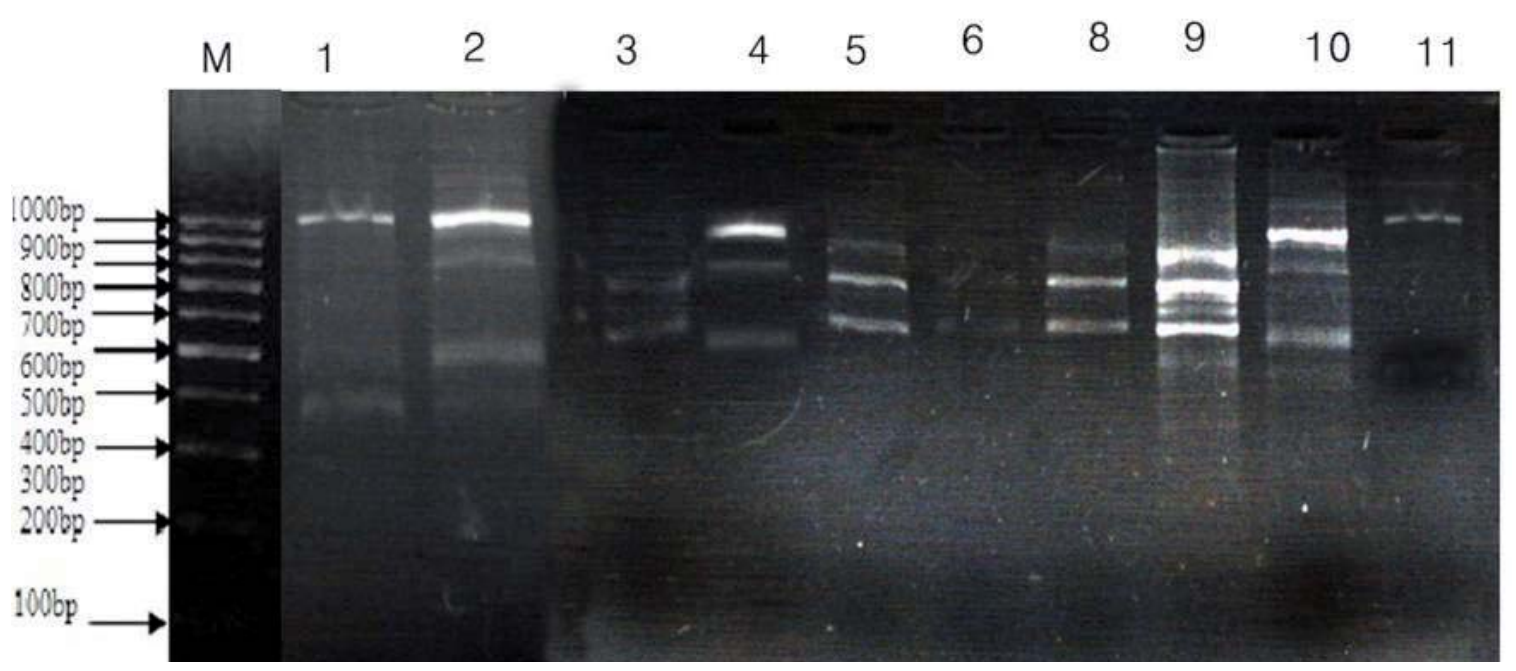

Fig. 8. Maize genomic DNA amplification with RAPD primer (OPA-13) along with molecular marker (1000p) from leaves of maize seedlings in both control (lane 1) and wastewater-stressed plants, i.e., $2(10 \% \mathrm{PW}), 3(50 \% \mathrm{PW}), 4(100 \% \mathrm{PW}), 5(10 \% \mathrm{MW}), 6(50 \% \mathrm{MW})$, $7(100 \% \mathrm{MW}), 8(10 \% \mathrm{WW}), 9(50 \% \mathrm{WW})$, and $10(100 \% \mathrm{WW})$.

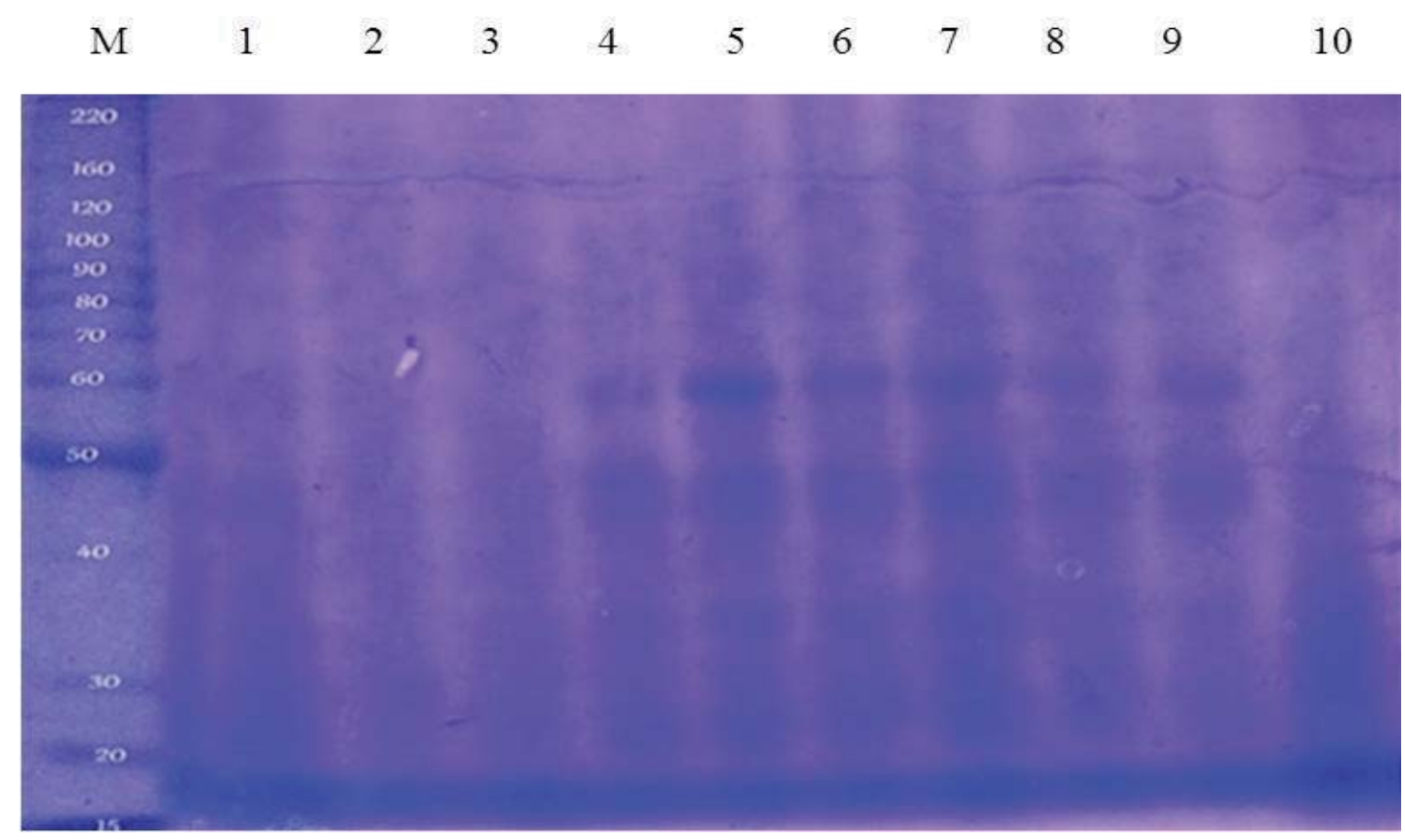

Fig. 9. 1-D gel image of crude proteins extracted from leaves of maize seedlings in both control (lane 1) and wastewater-stressed plants, i.e., 2(10\% PW), 3(50\% PW), 4(100\% PW), 5(10\% MW), 6(50\% MW), 7(100\% MW), 8(10\% WW), 9(50\% WW), and 10(100\% WW).

progressive increase at all concentrations from 10 to $100 \%$ as compared to control (Fig. 7(b)). In the case of MW-treated samples, POD activity increases from $10 \%$ (16 mM/g FW) to $100 \%$ (18 mM/g FW ) concentrations. In the present study, its activity enhanced in all sewagetreated plants with the increase in concentration of wastewater.

CAT is necessary for ROS detoxification and has the potential to break off the $\mathrm{H}_{2} \mathrm{O}_{2}$ into $\mathrm{H}_{2} \mathrm{O}$ and $\mathrm{O}_{2}$ [29]. An increase in CAT activity was recorded in maize seedlings under sewage stress (Fig. 7(c)). In comparison to controls, its mean values increased with the enhancement in the concentration of wastewater in all three samples. Increases in the antioxidant enzymes' activities with the increase in the concentrations of sewage stress levels reveal that maize seedlings are capable of coping with the stressful situation caused by sewage water.

\section{Genotoxic Effects of Wastewater on Maize Seedlings}

The changes in DNA caused by heavy metals present in wastewater may be monitored by RAPD profiles [31]. Ten different RAPD primers were used in order to study 
the genotoxic effects of wastewater on maize seedlings. Out of these 10, four were given amplified total genomic DNA of leaves of maize seedlings. A representative picture of OPA-13 is given in Fig. 8. There appeared a number of polymorphic bands in wastewater-treated samples of leaf DNA.

1-D gel image of the total crude proteins of leaves is shown in Fig. 9. According to the figure, some minor bands with an increase in wastewater concentration appeared in the growth media. MW wastewater showed major bands of all three concentrations with the size of 20,50 , and $60 \mathrm{KDa}$. WW wastewater-treated plants showed minor protein banding patterns of sizes 59 and $46 \mathrm{KDa}$ in 10 and $50 \%$. Similar results were obtained by Li et al. [32].

\section{Acknowledgements}

The project was jointly supported by 973 Project of National Natural Science Foundation of China and Kohat University of Science and Technology, Kohat, Pakistan.

\section{Conclusion}

All types of wastewater cause stressful situations in maize seedlings at almost all levels. There was an upregulation of the antioxidative metabolism in maize seedlings. Further studies need to be carried out to get deeper knowledge about the presence of the toxic materials as well as their nature.

\section{References}

1. POSTEL S.L., DAILY G.C., EHRLICH P.R. Human appropriation of renewable fresh water. Sci. 271, 785, 1996.

2. LIU W.H., ZHAO J.Z., OUYANG Z. Y., SOLDERLAND L., LIU G. H. Impacts of sewage irrigation on heavy metal distribution and contamination in Beijing, China. Environ. Inter. 32, 805, 2005.

3. HORSEWELL J., SPEIR T. W., VAN SCHAIK A.P. Bioindicators to assess impacts of heavy metals in the land applied sewage sludge. Soil Biol. Biochem. 35, 1501, 2003.

4. WANG H., YANG Z.M. Copper induced stress and antioxidative responses in roots of Brassica juncea L. Bot. Bull. Acad. Sinica. 45, 203, 2004

5. MADYIWA S., CHIMBARI M., NYAMANGARA J., BANGARIA C. Cumulative effects of sewage sludge and effluent mixture application on soil properties of a sandy soil under mixture of star and Kikuyu grasses in Zimbabwe. Phys. Chem. Earth. 27, 747, 2002.

6. TÜRKEZ H., TURGAY S., UMIT D., FATIME G., TATAR A., KELES M. S. The genotoxic and biochemical effects of wastewater samples from a fat plant in Erzurum. BAÜ FBE Dergisi Cilt. 11, 55, 2009.

7. DAUD M.K., QUILING He., LEI M., ALI B., ZHU S.J. Ultrastructural, metabolic and proteomic changes in leaves of upland cotton in response to cadmium stress. Chemos. 120, 309, 2015

8. MARYAM S., MOHESENZADEH S., MOHABATKAR $\mathrm{H}$. Cadmium induced genotoxicity detected by the random amplification of polymorphism DNA in the maize seedling roots. J. of Cell and Mole. Res. 2, 42, 2010.

9. AHMED S., SALEEM M. A., RAUF I. Field efficacy of some bioinsecticides against Maize and Jowar stem borer, Chilo partellus (Pyralidae: Lepidoptera). Int. J. Agric. \& Biol. 4, 332, 2002.

10. NAZ F., HUSSAIN M., DIN M. Insect pests of maize and their losses. Asian J. Plant Sci. 2, 412. 2003.

11. RAI P. K., KUMAR G. The genotoxic potential of two heavy metals in inbred lines of maize (Zea mays L.). Turk. J. Bot. 34, 39, 2010.

12. AWAN J.A., SALIM U.R. Food analysis manual. Vet. Agric. Publication. 5, 2, 1997.

13. BERNSTEIN N., SHORESH M., XU Y., HUANG B. Involvement of the plant antioxidative response in the differential growth sensitivity to salinity of leaves vs roots during cell development. Free Radical Biol Med. 49, 116, 2010.

14. DAWOOD M., CAO F., JAHANGIR M.M., ZHANG G., WU F. Alleviation of aluminum toxicity by hydrogen sulfide is related to elevated ATPase, and suppressed aluminum uptake and oxidative stress in barley. J. Hazard. Mater. 209, 121, 2012.

15. CENKCI S., YILDIZ M., CIG ERCI I.H., KONUK M., BOZDAG A. Toxic chemicals-induced genotoxicity detected by random amplified polymorphic DNA (RAPD) in bean (Phaseolus vulgaris L.) seedlings. Chemos. 76, 900, 2009.

16. LAEMMLI U. K. Cleavage of structural proteins during the assembly of the head of bacteriophage T4. Nat. 227, 680, 1970.

17. NAGDA G.K., DIWAN A.M., Ghole V.S. Seed germination bioassay to assess toxicity of molasses fermentation besed bulk drug industry effluent. Elec. J. Env. Agri. Food Chem. 5, 1598, 2006.

18. SHAKOOR M.B., ALI S., FARID M., FAROOQ M.A., TAUQEER H.M., IFTIKHAR U., HANNAN F., BHARWANA S.A. Heavy metal pollution, a global problem and its remediation by chemically enhanced phytoremediation: A Review. J. of Biodiver. and Environ.1 Sci. 3, 12, 2013.

19. SINGH K.P., MOHON D., SINHA S., R. Dalwani. Impact assessment of treated/untreated wastewater toxicants discharge by sewage treatment plants on health, agricultural and environmental quality in wastewater disposal area. Chemos. 55, 227, 2004.

20. SHEKHAWAT G. S., VERMA K., JANA S.,SINGH K., TEOTIA P., PRASAD A. In vitro biochemical evaluation of cadmium tolerance mechanism in callus and seedlings of Brassica juncea. Protoplas. 239, 31, 2010.

21. DOKE K.M., KHAN E.M., RAPOUL J., SHAIKH A. Physico-chemical analysis of sugar industry effluent and its effect on seed germination of Vigna angularis, Vigna cylindrical and Sorghum cernum. Ann. Environ. Sci. 5, 7, 2011.

22. DASH A.K. Impact of domestic wastewater on seed germination and physiological parameters of rice and wheat. Int. J. Res. \& Rev. Appl. Sci. 12I, 280, 2012.

23. KHAN N.A., SAMIULLAH S.S., NAZAR R. Activities of antioxidative enzymes, sulphur assimilation, photosynthetic activity and growth of wheat (Triticum aestivum) cultivars differing in yield potential under cadmium stress. J. Agron. Crop Sci. 193, 435. 2007.

24. BAZAI Z.A., ACHAKZAI A.K.K. Effect of waste water from Quetta city on germination and seedling growth of lettuce (Lactuca sativa L.). J. Appl.Sci. 6, 380, 2006. 
25. HUSSAIN I., IQBAL M., NAWAZ M., RASHEED R., PERVEEN A., MAHMOOD S., YASMEEN A., WAHID A. Effect of sugar mill effluent on growth and antioxidative potential of maize seedling. Int. J. Agric. \& Biol. 15, 1227.

26. JIN X., YANG X., ISLAM E., LIU D., MAHMOODQ. Effects of cadmium on ultrastructure and antioxidative defense system in hyperaccumulator and non-hyperaccumulator ecotypes of Sedum alfredii Hance. J. Hazard. Mater. 156, 387, 2008.

27. QUAN L.J., ZHANG B., SHI W.W., LI H.Y. Hydrogen Peroxide in Plants: A versatile molecule of reactive oxygen species network. Journal of Integrative Plant Biology. 50, 2, 2008.

28. SHARMA P., JHA B., DUBEY R.S., PESSARAKLI M. Reactive oxygen species, oxidative damage, and antioxidative defense mechanism in plants under stressful conditions. J. Bot, 2012: Article ID 217037. 2012.

29. GILL S.S., TUTEJA N. Reactive oxygen species and antioxidant machinery in abiotic stress tolerance in crop plants. Plant Physiol. Biochem. 48, 909, 2010.

30. RAZINGER J., DERMASTIA M., KOCE J. D., ZRIMEC A. Oxidative stress in duckweed (Lemna minor L.) caused by short-term cadmium exposure. Environ. Pollut.153, 687, 2007.

31. SAVVA D. Use of DNA fingerprinting to detect genotoxic effects. Ecotoxicol. Environ. Saf. 41, 103, 1998.

32. LI X., MA H., JIA P., WANG J., JIA L., ZHANG T.,YANG Y.,CHEN H., WEI X., Responses of seedling growth and antioxidant activity to excess iron and copper in Triticum aestivum L. Ecotoxicol. Environ. Saf. 86, 47, 2012. 
